Please do not remove this page

RMIT

UNIVERSITY

\title{
Project-based learning as a contributing factor to graduates' work readiness
}

Jollands, Margaret; Jolly, Lesley; Molyneaux, Thomas

https://researchrepository.rmit.edu.au/esploro/outputs/9921862106201341/filesAndLinks?institution=61RMIT_INST\&index=null

Jollands, M., Jolly, L., \& Molyneaux, T. (2012). Project-based learning as a contributing factor to graduates' work readiness. European Journal of Engineering Education, 37(2), 143-154.

https://doi.org/10.1080/03043797.2012.665848

Document Version: Accepted Manuscript

Published Version: https://doi.org/10.1080/03043797.2012.665848

Repository homepage: https://researchrepository.rmit.edu.au

(C) 2012 Copyright SEFI

Downloaded On 2023/04/27 00:28:39 +1000

Please do not remove this page 


\section{DMIT \\ UNIVERSITY}

Thank you for downloading this document from the RMIT Research Repository.

The RMIT Research Repository is an open access database showcasing the research outputs of RMIT University researchers.

RMIT Research Repository: http://researchbank.rmit.edu.au/

\section{Citation:}

Jollands, M, Jolly, L and Molyneaux, T 2012, 'Project-based learning as a contributing factor to graduates' work readiness', European Journal of Engineering Education, vol. 37, no. 2, pp. $143-154$.

See this record in the RMIT Research Repository at:

http://researchbank.rmit.edu.au/view/rmit:17998

Version: Accepted Manuscript

Copyright Statement: (c) 2012 Copyright SEFI

Link to Published Version:

http://dx.doi.org/10.1080/03043797.2012.665848

PLEASE DO NOT REMOVE THIS PAGE 


\section{Project based learning as a contributing factor to graduates' work readiness}

Margaret Jollands ${ }^{\mathrm{a}^{*}}$, Lesley Jolly ${ }^{\mathrm{b}}$ and Tom Molyneaux ${ }^{\mathrm{a}}$

${ }^{a}$ School of Civil, Environmental and Chemical Engineering, RMIT University, 124 La Trobe St, Melbourne, Australia, Tel:+61 3 99252208, Fax:+61 3 99253746; ${ }^{b}$ Engineering Architecture, and Information Systems, University of Queensland, Brisbane, Australia, Tel: +61 73365 3533, Fax:+61 73365 4444;

(Received 3 September 2011; final version received 9 February 2012)

\footnotetext{
* Corresponding author. Email: margaret.jollands@ @rmit.edu.au
}

*Corresponding author. Email: margaret.jollands@ rmit.edu.au 


\title{
Project based learning as a contributing factor to graduates' work readiness
}

\begin{abstract}
This paper explores what work readiness means for two cohorts of graduate engineers, one from a traditional curriculum, the second from a largely project based curriculum. Professional bodies and employers have defined a set of attributes for engineering graduates so that graduates will be 'work ready'. Problem based learning (PBL) is claimed to be a suitable approach to develop such skills. The graduates were interviewed some months after starting work, along with their managers. All the graduates recognised the benefits of taking PBL subjects as well as vacation work, with success in communication attributed more to PBL. Both cohorts had similar learning outcomes, high skill levels in project management, problem solving, communication skills, research and sustainability. A skills gap in ethics was identified for both cohorts of graduates and their managers. Further work is planned to link skill development with undergraduate learning experience.
\end{abstract}

Keywords: Project based learning; Assessment of learning outcomes; Engineering Education; Evaluation

\section{Engineers Australia - providing a framework of 'work-readiness'}

Professional bodies have been questioning whether engineering graduates have the right attributes for over twenty years (ASEE 1994, IEAust 1996). A consistent finding is that students acquire technical knowledge but are limited in their able to apply it. An analysis of the key transferable skills of chemical engineering graduates, based on self reports from both graduates and their supervisors, concluded graduates' skills to be 'insufficient to meet the needs of employment' (Grant \& Dickson, 2006). Another recent study (Nair, Patil \& Mertova, 2009) identified similar short-comings: a competency gap was found between graduates' professional attributes and the expectations of their employers, in areas such as communication and problem solving skills, social skills including leadership, emotional intelligence and the ability to work with people of difference.

The seminal Henley Report (Spinks, Silburn \& Birchall, 2006) was commissioned by the Royal Academy of Engineering and surveyed over 400 engineering companies within the United Kingdom. It identified a need to "overhaul undergraduate engineering education". The biggest concern was graduates' ability to apply knowledge to industry problems. The report identified a need to better prepare graduates for positions within workplaces increasingly characterised by management complexity and globalization. It also identified environmental sustainability as a need, although its importance depended on the industry sector. The study concluded that to operate successfully in the current business environment, graduates need to "combine technical expertise with practical ability, backed up by strong interpersonal skills, including an awareness of commercial realities". In particular, employers reported that the most sought after graduates were able to engage in problem solving with drive and energy. Sustainability was identified by some as a desirable attribute but it received less attention "than might have been expected". The report does not define exactly what 'practical ability' might look like but it is clear it is something to do with approaches to problem solving that involve communication with other people. For educators the question is how to present practice in such skills within the curriculum.

A key outcome from these studies and reports is that graduate engineers should have skills beyond the narrowly technical, so that when they commence employment they are 'work-ready'. In this study we explore the concept of work readiness based on our discussions with recent graduates and their immediate line managers.

Engineers Australia (EA) is the professional accrediting body for engineering degrees in Australia. It sets the standards expected of new graduates entering the professional engineering workforce. EA's recently revised Stage 1 Competency Standard (Engineers Australia 2011) describes the characteristics of a mature professional engineer in terms of Knowledge and Skills, 
Engineering Application Ability and Professional and Personal Attributes. The attributes have six "elements of competency" including ethics, communication, creativity, using information, professional conduct and being a good team member.

In the light of the EA Competency Standard, as well as the growing need of employers for graduates with skills beyond just the technical, RMIT University School of Civil, Environmental and Chemical Engineering took the decision in 2001 to move to away from a traditional curriculum to a problem based learning one. This was implemented in 2004/5, with first graduates in 2007/8. The implementation is described elsewhere (Jollands et al, 2005). The program design was aligned with EA competencies and a stream of projects was embedded from first to final year in problem based learning subjects.

\section{Problem Based Learning}

Problem based learning (PBL) starts with an ill-defined problem, and the student must work out from the application what theory needs to be learnt, compared to traditional programs, where students begin with theory and progress to application (Prince \& Felder, 2006). Various claims for PBL include: it supports development of high-level cognitive abilities and practice skills (Woods 1994); it develops student skills of team work, communication, research, critical analysis, life long learning and solving real world problems (Duch, Groh and Allen 2001); it offers students opportunities to build more meaningful connections between learning experiences than the small, fragmented assessment tasks typical of traditional courses (Boud 2010).

PBL has been widely adopted in medical education because it allows students to acquire not only content knowledge but knowledge of and practice in the professional behaviour of a physician (Perrenet, Bouhuijs \& Smits, 2000). PBL is also well suited to teaching engineering undergraduates. Mills and Treagust (2003) reported PBL is appropriate in engineering schools because "almost every task undertaken in professional practice by an engineer will be in relation to a project". Litzinger et al (2011) recommend PBL for engineering undergraduates, as it is one of the best approaches to develop all of the requisite skills and knowledge.

Many universities around the world have implemented PBL in their undergraduate engineering programs, such as McMaster University, Canada, and Aalberg University, Denmark, and in Australia, University of Queensland and University of South Australia (Litzinger et al 2011).

Interestingly, while a number of studies have been carried out to assess whether PBL is effective once graduates enter the workplace, relatively few studies considered engineering programs, and of those few, the outcomes are conflicting. None have been undertaken in Australia. A study of Aalborg engineering graduates found them superior to graduates from traditional programs on a range of skills, including project management and creativity (Kjaersdam 2004). A major pan-European study by Segalas and co-workers (2009) concluded that for the competency of sustainable development "Students achieve more cognitive learning as more community-oriented and constructive-learning pedagogies are applied." Better learning outcomes were achieved with active learning pedagogies, such as PBL, and from group community projects, rather than individuals learning independently.

However, a recent meta-study of PBL by Walker and Leary (2009) suggested the picture is not so clear. They compared effectiveness of PBL programs from a variety of disciplines with traditional programs and found no conclusive case for PBL being better or worse than traditional programs for medicine, science or engineering. PBL showed "essentially identical outcomes as lecture-based approaches". This was attributed to "a large amount of variance among the findings", which correlated with variance in the way PBL was implemented. Only teacher education studies showed PBL delivering better outcomes than a lecture-based approach. In terms of implementation, significantly better learning outcomes were achieved in PBL subjects where design problems were investigated by students, while the best outcomes were achieved with "closed loop" PBL, where 


\section{M.Jollands et al.}

students review their research process at the end of semester and identify if they could make any improvements in it (Walker and Leary 2009).

While it seems self evident that PBL subjects will provide students with more opportunities to develop non-technical skills, the need continues for engineering education research to deliver compelling evidence of what benefit this brings to graduates. This paper explores what work readiness means for two cohorts of recent engineering graduates, one from a fairly traditional curriculum, and one from a more substantially project based curriculum. The data were collected through interviews with the graduates and their managers. The interviews were held when the graduates had been in employment for a few months to 2 years. Similarities and differences between the two cohorts are identified. The impact of vacation work on learning outcomes is compared with that of PBL subjects. Confounding factors are identified.

\section{Research Method}

Participants in this study were graduates of the School of Civil, Chemical and Environmental Engineering [Table 1]. Our call for volunteers was sent by email to graduates in our alumni email database. We selected graduates whose managers were also willing to participate in the study. In total we interviewed 10 graduates and 10 managers. 8 graduates were from Chemical Engineering and 2 from Civil Engineering. The ratio of male to female participants was 1:1. This reflects the high proportion of female students in Chemical Engineering $(\sim 30 \%)$. Four of the participants undertook their studies from what is considered to be a traditional engineering curriculum. Within their program of study, students undertook only one or two PBL subjects. These participants graduated in 2007, so at the time of interview had worked for 1 to 2 years. The other six participants undertook their studies from a curriculum with a significant proportion of PBL subjects. The ratio of PBL to traditional subjects was 1:3, that is, one PBL and three traditional subjects per semester over the whole duration of the program. These participants graduated in 2008, so at the time of interview had worked for 5 months to a year. All participants had undertaken vacation work for 12 weeks over a summer, or a gap year.

The companies where the graduates worked included a range of typical chemical and civil engineering industries: the water industry, oil and gas, consultants and higher education.

The interviews were done individually, were recorded and then transcribed verbatim. Each interview lasted between 30 and 60 minutes. The interviews adopted a semi-structured approach with questions based on a set of desirable work-ready attributes (Engineers Australia, 2011). Graduates were asked to talk about the nature and context of their current project, the role they had within that project including the technical competencies expected of them, their project team and its interactions, successes and difficulties experienced as well as the strategies they employed to keep current with the specific intellectual demands of that their project. Supervisors were asked to talk about the role of their graduate, and their behaviour when undertaking projects.

The transcriptions were analysed thematically with a qualitative phenomenological approach. Data emerging from the interviews were grouped together in competencies (Engineers Australia 2011). Links to learning outcomes in undergraduate subjects were identified. We sought to identify what aspects of their undergraduate experiences assisted with their transition into the workplace.

\section{Findings}

Many of the outcomes and competencies are described in very general terms. We use the participants' words to clarify what each of the outcomes means in everyday practice. We also report where the graduates specify links between acquisition of skills and learning experiences such as project-based subjects. A summary of the frequency of links between attributes and PBL subjects and vacation work is given in Table 2 . 


\subsection{Project management}

Having the ability to manage time and processes effectively is an essential competency identified by Engineers Australia (2010) and one that PBL in particular aims to develop. In this regard, some of the graduates seem to have struggled learning to juggle their time with the multiple tasks involved. PBL3 admits that learning to manage time was difficult for her; "trying to manage the work that we are doing with other projects as well everyone has got their own things going on and so if a project gets delayed then you have to schedule it again". Non-PBL2 describes her experience of getting a project going or "getting the ball rolling" as the hardest part of being a new graduate. With the wisdom of some experience she reflects:

A lot of that comes down to knowing what to do next and understanding the work processes on how change happens...in the beginning you are so blind and they assume that you know all of the steps that you have to go through, and sometimes...I didn't know what I needed to do.

\section{Non-PBL2 also said}

I would have loved to have done more project based stuff like the final year design project before becoming an engineer.

Reported confidence in project management skills was linked to the graduates' university experiences. PBL6 reflects that his "project-based [subjects] definitely helped me... you have to do the technical subjects too of course but with the project stuff it's what you're more likely to be doing at work". Similarly, PBL5 recalls one particular project in third year that prepared him for employment because it mirrors his current task in industry. Another graduate, non-PBL4 reflects on a research project he did at uni as "very useful" in his current position.

Confidence was also linked to undertaking vacation work. PBL1 said "I was reasonably confident to enter the workforce based on the work experience that I had". PBL3 commented "I've certainly grown in confidence as I have gone along, I think doing vacation work and sort of part time work really helps your position". Non-PBL3 also commented "So I think the experience at [company] was really very useful for me in terms of communication and self confidence".

Both PBL and non-PBL graduates recognise the benefits of undertaking project work for project management skills, time management and confidence. Confidence was also linked to vacation work. This reveals two of the confounding factors in this study. Firstly, both cohorts had done project based subjects: the non-PBLs did one or two, and the PBLs eight. Secondly, all students had done vacation work or a year work placement.

Not surprisingly, the supervisors tended to be very supportive and non-critical of their recent graduates' capabilities. However the focus of their comments suggests that some attributes are particularly valued. One of these relates to project management skills or 'getting things done'. One supervisor talked of her graduate's (PBL3) ability to initiate contact with others; solve problems and "get things done". Similarly PBL4's supervisor recognized that her graduate did a good job "in terms of making sure that her scope was clear and all of the key components were articulated well". Another supervisor observed of his graduate (non-PBL2) that she consulted to see "if we were running at where we were expecting to run and if we weren't then to try and understand why and coming up with a way of correcting it". Both PBL and non-PBL graduates were recognised by managers as having project management skills. 


\subsection{Problem solving}

The ability to address and solve problems lies at the heart of project based learning. One graduate (Non-PBL3) ascribes thinking logically through an inquiry process as her successful strategy:

For example when sizing the equipment if something doesn't agree the numbers are like all over the place, so like where do you start... why is it different...so there was another challenge, but it proved really useful, just logical thinking... like don't get scared of something you don't know, just think logically... why is it different, what could cause it.

To illustrate this process, graduate non-PBL1 tells of needing to design a specific tank: "I based it on other people's stuff, but I adapted it for my purposes got the basic design from papers that I read and by adapted I mean severely adapted". The supervisor acknowledges the graduate's skills in this area:

His problem solving skills are good ... I come from [one] engineering background and he comes from [another] engineering background which often shows in the ways that we look at things so it's quite complicated and in that sense I see a lot of value ... I was glad that he is capable of making that sort of decision, and changing my way of thinking too in some cases.

There is also clear evidence that problem identification is important. PBL4 listed this as the hardest part of her job: "I was sort of like 'we have to refocus this', and I was like 'this, this, this, these parts here - are they really going to answer this question?"'. As with project management, there was clear appreciation that definitions had to be relative to industry needs and the needs of the overall project. This was summed up by non-PBL4:

It was pretty tough, because there's been absolutely no work done in this field before ...we had to go back to square one and think 'oh well, what can we do now - we've got all the data now, try and fit it into some kind of usable outcome for the industry. And the guidelines is what we came up with.

Most of the PBL and non-PBL displayed some level of skill in problem solving, with some reporting a skill gap, but none linked their skill to PBL coursework or vacation work. This suggests that undergraduates would benefit from more explicit training in this area.

\subsection{Communication and consultation}

The crucial importance of effective communication skills is reflected in every published study of the desired graduate attributes of engineers. From the interview data it is clearly evident that communication and consultation take up a significant amount of the graduates' time. As one supervisor observes, "liaising with people... is the main part of the job". The interview data reveals that graduates are expected to liaise and consult for a range of purposes. During the transition period, liaising with colleagues to get support and advice proved to be a crucial skill. PBL4, who describes defining problems as the hardest part of her work, reports finding assistance through her contact with others:

I worked with a few people from research and technology as well just to get their opinions on it...well at the start of the project I organised actual meetings, sit down 'lets go through this', that's sort of thing, now I pretty much...just pick up the phone and say 'how's it going' but still if there's things about data that I don't understand and I'll go to research and technology ...some of the process people, I'll talk to them if there's something I' $m$ not quite sure about .... 
Another graduate (non-PBL4) reported that a lot of his communication is with people outside the discipline field:

There was also a micro-biologist...who I liaised a lot with and obviously the project had a steering committee, which had all sorts of people on it.....just experts from all these different backgrounds, which was a challenge in itself, just trying to talk to everybody in a language that was appropriate to them, sort of thing.

In her interview, Non-PBL3 addresses the tension between asking too many questions or being more independent and identifies that it was her vacation work experiences that helped her make these judgements:

...if something isn't clear, I just ask... what I learnt from my previous [vac work] experiences, instead of sitting, and thinking, 'maybe this is not his way, maybe this is not right', and spending all this time thinking and making things even more complicated, because you think more about it, it's just more simple to go and ask someone... but another thing is not to go to the other extreme and not to think about it, and just go and ask, like 'I'm too lazy to think about it so I'll just go and ask', like it's about trying to balance those two.

Supervisors also recognized the value of effective, productive communication. PBL3 is described by her supervisor as someone who is prepared to "approach people and ask questions". Similarly, non-PBL4 was described by his supervisor as someone who "didn't have any problems with asking for help internally". The employer attitude to communication skills is summed up in the comment "it's about how you communicate the technical knowledge across a range of people with varying backgrounds, varying opinions and levels of understanding".

Communication with clients is often left until graduates get a little more experience. PBL5's ability to communicate effectively was noted by his supervisor: "I think his communication skills are really good... he communicates very well ... it's not a problem putting him in front of a client to discuss the project, he understands the project and he can express himself reasonably well". Similarly, PBL2 received approval from his supervisor: "[He's] been in direct contact with clients, and handled that pretty well, which is a pretty good effort for a recent graduate... he's moved into other projects into roles where he is dealing directly with clients, so that says a lot". PBL3 attributes her ability to "work with people ... sort of work with different people from different sort of areas" to her "definitely useful" PBL classes at university.

Report writing is another communication skill expected of an engineer. PBL graduates reported a higher level of confidence in their skills than non-PBL. When asked what was the easiest part of his current project, PBL2 commented "I guess probably reporting.... in each of those projects that we had done at uni we had to provide a report at the end, so that was at least 8 reports I believe, of a uni course". PBL4 was critical of other engineers who had not done PBL subjects: "sometimes you get reports from consultants and you're like 'obviously you never wrote a report at uni". Non-PBL4 admits that in this regard he also struggled: "I had to write a lot of reports .... in the beginning I didn't have much confidence in what I was doing ... I was given a job to write this report and it was just very much inadequate." When supervisors were asked about their graduates' capabilities in this regard, the responses were varied. PBL5's supervisor delicately comments that: "he could improve his written skills a bit...if he was to write a report, he would need a bit of a hand with that".

The communication described here is mainly interpersonal communication. Both PBL and non-PBL graduates self reported and were recognised by their managers as having a high level of communication skills. PBL graduates were more likely to attribute their confidence in communication to undertaking PBL subjects where non-PBL graduates attributed it to vacation work (Table 2). This is consistent with the literature, that PBL develops communication skills 
(Duch, Groh and Allen 2001). At RMIT the focus is on report writing and formal presentations in both the traditional and PBL curriculum focus. So it is somewhat surprising that when graduates and employers identify a gap, it is in report writing. This suggests that even the PBL undergraduates would benefit from more training in report writing.

\subsection{Sourcing information}

Sourcing or researching information is an integral dimension of the work of an engineer and one that is expected to be put into practice from the time the graduate gains employment. All the graduates were confident in their ability to source information, and employed a variety of strategies. Nearly everyone mentioned tapping on the expertise of people in their immediate work team or in the company more widely - another communication skill. The internet was another popular source. Larger companies maintained an intranet which graduates could use. Old university notes and textbooks were used. Only one employer was less than happy with their graduate's [non-PBL1's] ability to access information and this may have been an issue of initiative:"Say if he can't find a standard... he tried a couple of times and he didn't tell me that he couldn't find it. I told him that if he wants to find something, he can that's the reason for many people getting things done". The PBL and non-PBL graduates displayed a similar high level of research skills but while it seems likely some of their skills were honed in project based subjects (Duch, Groh and Allen 2001), none linked their skill to PBL coursework or vacation work. Further work will be undertaken to explore the links between development of research skills and undergraduate learning experiences.

\subsection{Awareness of sustainability}

Addressing the sustainability implications or impacts of products or processes is a requirement of Engineers Australia and other accrediting bodies. The sustainability of a project is an integral element in all the RMIT PBL subjects. Most of the graduates were able to comment on sustainability aspects of their current projects. Non-PBL2 spoke passionately on her perspectives concerning sustainability and the pressing need for industry to adopt best practice. Non-PBL3 spoke about the balance of economic and environmental aspects, describing investment upfront to yield environmental benefits down the track. Non-PBL4 described "Well it was designed and the whole idea behind it was to improve water recycling in the car wash industry and to improve the instances of that, reliability behind it, so the end result was to build more confidence in water recycling in the car was industry". PBL3 noted that "the main thing is the relationship with the neighbours as well, like contamination, because a lot of people get concerned with what we are doing, that sort of thing. So yeah, we are trying to manage that". PBL4 could describe the implications of her project in detail: "Yeah, so sustainability at [company] is generally very much a priority". PBL6 was able to articulate potential tension between sustainability and economic factors: "everything we do we try to make it as environmentally friendly, and to make it last, and to be the solution for the longest period of time, not just a band-aid sort of thing. We try to get the best value for our money, you know the work we do we don't want to come back a year later and do it all again". Although PBL5 admits that sustainability is not something he has thought of, he is able to describe what it means to some extent in his current workplace; "in saying that we try to use sustainable materials for building, like pine products... I do try and apply that to my other projects like reducing the amount of steel as well". Only one graduate (non-PBL1) was unable to describe any sustainability aspects of the project. This suggests that their University training - both traditional and PBL - is equally effective, as the graduates can apply sustainability concepts to their current projects. This finding is at odds with the claims of Segalas and co-workers, that PBL is superior to traditional pedagogy in teaching sustainability. This may be attributed to the different measurement tools used in the two studies, and the longer work experience of the non-PBL graduates compared to the PBL graduates (Table 1). Further work will be undertaken to explore the links between developing an 
understanding of sustainability and teaching pedagogy using Segalas' methodology for measuring student learning.

\subsection{Ethical Considerations}

Understanding ethical implications of project decisions is recognized as an important graduate attribute. While some could describe ethical implications of their project, both graduates and managers struggled with this question. Non-PBL2 gave an impressive example of alignment of personal and company commitment to ethical decision making:" I remember one of the questions in the interview was 'if we made a batch of off spec product, ..., what do you do?'.... And certainly their response to that question was one of the reasons why I took the job, because I feel that is the kind of business I want to work for". Non-PBL4 gave a good example of ethical implications of group work: "the conflict of interest in some of the people in the committee might be... about the certain representatives that were really behind the research because they thought it would push their systems ahead of everyone else's". PBL5 had already had direct experience: "Well recently I guess it was just a dodgy contractor, when I looked up at the beam and I realised that the beam was actually in two pieces, welded together, but in the shop drawings it showed it as one continuous piece so I pointed that out to my manager, like 'is that right, it doesn't look right to me - this is a very highly loaded beam, it shouldn't be like that'”. PBL6 also gave a good example of ethics: "Yeah, you've got to make sure you're not biased towards someone you know, like with contractors, you don't want to be corrupt like that". Managers examples of ethical implications of the graduate's project included from one, "[if] someone did something really stupid, like an act of vandalism or sabotage or something", and from another, "Yes, the intellectual property agreement, he signed that".

Others' answers were vague or showed confusion between what is ethical, legal, and public relations (PR). Non-PBL3 commented; "the first thing when we are doing a job we have to meet the legal requirement", which shows a misunderstanding of the difference between ethical and legal. PBL3 defined ethical practice as "probably managing the relationship with the neighbourhood where we work in, and people might say to us what are we doing" and went on to say "the project that I'm involved in I've been given clear direction on what to say, how to sort of refer it back to the public relations people", which suggests the concern is more about PR than ethical behaviour. PBL4 drew upon a working mantra; "everything we do is supposed to be ethical so that's always in the back of your head is this the right thing to be doing?" but was unable to give any specific examples. PBL1 was unable to think of any ethical factors associated with her work because "my project doesn't involve people". Similarly PBL2 was unable to identify any ethical issues; "um ethical issues, um in terms of my involvement or the companies? ... I'm not sure... I can't think of any ethical issues ... not for this project".

Some of the employers had a minimal idea or failed to grasp the ethical implications of their graduate's projects. One commented, "Being engineers, we have a charter of ethics to the community as well" and then continued "With certain questions, you have to refer them on to the PR people", again showing confusion between PR and ethics. Another commented "Yeah a strong focus of the industry group was that they didn't want to offend any of their members", confusing ethics with group leadership. Another commented about a soil remediation project "I can't see anything that's a major [ethical] issue in it... but probably in terms of ethical issues there is potential for the data to be faked". Two commented that there were no ethical issues for their graduate's project "Ethical? I don't know. Let me see..... no, none, no ethical issues pertaining to this project" and another said, "No I don't think there are any. Not that I'm aware of. Not really related to this project". The comments of two of the engineering managers were very surprising: "I've been an engineer working for twenty years now, and ethical issues don't really come along that often, fortunately." and "Um... not quite sure what you mean by ethical"! 
Only about half of the graduates were able to identify ethical implications of their projects competently, and most of the employers struggled to do so. None linked their knowledge or skills to PBL coursework or vacation work. This suggests that both University and industry should offer more effective training in this area. Further work will be undertaken to explore the links between developing an understanding of ethics and student learning experiences.

\subsection{Technical skills}

Comprehensive understanding of engineering principles is fundamental to being able to tackle problems and successfully complete projects and PBL and related approaches are often criticised for being deficient in this area. Both PBL and non-PBL students identified some technical difficulties. Comments included: "its not so much hard as it is I just don't have the knowledge" (PBL2) and "not knowing enough, like the chemical engineering background is so wide, so it covers so many disciplines, so what I found hard is doing the specific tasks that we didn't cover at uni" (non-PBL3). This finding is consistent with the literature, that PBL and non-PBL engineering programs have equivalent learning outcomes (Walker and Leary 2009).

\subsection{Systematic application of engineering knowledge in design}

A recurrent theme in both graduates' and employers' descriptions of good work performance was the ability to think logically, whether the issue was in defining and solving problems, identifying useful information sources or managing project activities. This closely mirrors the competencies ascribed to professional engineers by EA (2011). In the opinion of all of the PBL students and three of the non-PBL students this ability was fostered in project-based subjects. The following quote from PBL-1 is typical:

We did plenty of projects at uni that helped us prepare for this sort of thing. It's all different, it's written differently, but you get used to being analytical, how to look at things.- I think what's helped me a lot with transitioning to work is the fact that we did do so many design projects each year in our [PBL subject] each semester, and it gave us more confidence to present to people, and taught everyone how to think about things, like think about the results to get and those sorts of things, so that was a good part of our course.

\section{Discussion}

Recounts of experiences from recent graduates and their supervisors reveal that the graduates entered a variety of workplace contexts. Clearly no university experience is going to address all the future specific needs of its graduates. However, from the experiences recounted by the recent graduates in this study, descriptions of their transition to feeling 'work-ready' as a professional in industry, can be confidently linked to EA attributes such as project management, problem solving and communication. Work-readiness may be defined as a complex of generic attributes that allow graduates to apply their technical knowledge to problem identification and solving once they join the workforce.

There were a number of similarities between the two cohorts of students. By self-report, both PBL and non-PBL graduates recognised the benefits of undertaking PBL subjects as well as vacation work, to develop project management skills, time management, confidence, communication skills and systems thinking. This is consistent with the literature, that PBL and nonPBL engineering programs have equivalent learning outcomes. The managers recognised EA attributes in their graduates and were very supportive and non-critical of their capabilities.

By self-report the graduates also claimed skills in problem solving, research, and 
sustainability, but did not link their skills to undertaking undergraduate PBL subjects, nor to vacation work. However, it seems likely some of their skills were honed in project based subjects (Duch, Groh and Allen 2001, Segalas, Ferrer-Balas and Mulder 2009).

Some differences were also evident. The PBL graduates were more likely to attribute their confidence in communication to undertaking PBL subjects, where non-PBL graduates attributed it to vacation work.

This study suggests PBL and vacation work lead to development of attributes that contribute to graduates' work readiness, in particular, project management and communication (Table 2). A tentative conclusion is that the EA attributes of communication and systematic application of engineering knowledge in design are developed better by PBL than vacation work.

Some skill gaps were identified in the graduates. Some lacked problem solving and report writing skills. Only about half of the graduates were able to identify ethical implications of their projects competently. There appears to be scant knowledge of the EA Code of Ethics, no articulation of the concept of due diligence, and little recognition of safety or intellectual property as ethical issues. This suggests the ethics components of our subjects are too brief, carry too little weight, or fail to put ethics into context. The University should give consideration to more explicit training in the areas of problem solving, report writing, and ethics.

Several confounding factors were identified in this study. These include, both cohorts had done project based subjects, the non-PBLs had done one or two PBL subjects, the PBLs up to eight; all students had done vacation work or a year work placement; the non-PBLs had worked several months longer on average, as they had graduated the previous year. Hence only tentative conclusions may be drawn from the study.

PBL is reported to be superior to traditional pedagogy in teaching sustainability, but there was no evidence of superior outcomes for PBL graduates in this study. This may be attributed to the different measurement tools used in the two studies, and the longer work experience of the nonPBL graduates compared to the PBL graduates. Further work is planned to explore the links between development of research skills, sustainability and ethics with undergraduate learning experiences.

\section{Conclusions}

"Work readiness" is a useful concept to assess a graduate's transition to the workforce. It may be defined as a complex of generic attributes that allow graduates to apply their technical knowledge to problem identification and solving. Employer surveys report that new engineering graduates lack desired attributes, such as project management, problem solving, and communication skills. This means they aren't 'work ready'. Graduates from predominantly PBL or traditional (non-PBL) programs share many work ready characteristics, attributed to both types of program using project based learning as well as students undertaking vacation work. Our PBL and traditional programs appear to have equivalent learning outcomes, similar to reports in the literature. Both develop problem solving, research, and sustainability, and these are linked explicitly to undertaking PBL subjects and vacation work. Students self-report that skills in communication are attributed more to undertaking PBL subjects than vacation work.

Skill gaps are problem solving, report writing skills and ability to identify ethical implications of projects. More explicit training in these areas is needed.

Several confounding factors were identified in this study. Further work is planned to explore the links between undergraduate learning experiences and development of research skills, sustainability and ethics. 


\section{M.Jollands et al.}

\section{Acknowledgements}

Thanks to the RMIT School of Civil, Environmental and Chemical Engineering for financial support for this project (Small Research Grant 2009) and to our research assistants, Andrew McLean and Dr Sue Wright.

\section{References}

ASEE, 1994. The Green Report: Engineering education for a changing world. American Society of Engineering Education: Washington DC

Boud, D., 2010. Assessment 2020. Seven propositions for assessment reform in higher education. Australian Learning and Teaching Council. Available from: http://www.altc.edu.au/resource-studentassessment-learning-and-after-courses-uts-2010 [Accessed 3 December 2010]

Duch, B.J., Groh, S.E., and Allen, D.E. (Eds)., 2001. The power of problem-based learning: A practical "how to" for teaching undergraduate courses in any discipline. Stylus: Sterling, Virginia.

Engineers Australia., 2011. Stage 1 Competency Standard for Professional Engineer. [online]. Engineers Australia. Available from:

http://www.engineersaustralia.org.au/about-us/program-accreditation/\#standards [Accessed 3 December 2010]

Grant, C. D., and Dickson, B. R., 2006. Personal skills in Chemical Engineering graduates: The development of skills within degree programs to meet the needs of employers. Education for Chemical Engineers, 1, 23-29.

Kjærsdam, F. (2004). Technology transfer in a globalised world: transferring between and industry through cooperation and education. World Transactions on Engineering and

Technology Education, 3(1), 63-66.

IEAust, 1996. Changing the Culture: Engineering Education into the Future. Institution of Engineers Australia: Canberra, ACT.

Jollands, M., Ward, L., Hadgraft, R., and Grundy, I., 2005. Student Engagement in Project-Based Courses in First Year Chemical Engineering at RMIT University. 16th Annual Conference Australasian Association for Engineering Education (AAEE2005) 26 - 30 September 2005 Sydney. Available from: http://www.aaee.com.au/conferences/papers/2005/Paper/Paper167.pdf [Accessed 3 December 2010].

Litzinger, T.A., Lattuca, L.R., Hadgraft, R.G., Newstetter, W.C., 2011. Engineering Education and the Development of Expertise Journal of Engineering Education, 100(1), 123-150.

Mills, J.E., and Treagust, D.F., 2003. Engineering education - is problem-based or project-based the answer? Australasian Journal of Engineering Education. Online publication 2003-04. Available from: www.aaee.com.au/journal/2003/mills_treagust03.pdf [Accessed 25 November 2010]

Nair, C.S., Patil, A., and Mertova, P., 2009. Re-engineering graduate skills - a case study. European Journal of Engineering Education, 34(2), 131-139.

Perrenet, J.C,, Bouhuijs, P.A.J., and Smits, J.G.M.M., 2000. The suitability of problem-based learning for engineering education: theory and practice. Teaching in Higher Education, 5(3), 345-358. 


\section{M.Jollands et al.}

Prince, M.J., and Felder, R.M., 2006. Inductive teaching and learning methods: Definitions, comparisons and research bases. Journal of Engineering Education, 95(2), 123-138.

Segalàs, J., Ferrer-Balas, D. and Mulder, K.F., 2009. Introducing Sustainable Development in Engineering Education: Competencies, Pedagogy and Curriculum. SEFI Annual Conference, 1-4 July 2009 Rotterdam. Available from: http://www.sefi.be/wp-content/abstracts2009/Segalas.pdf [Accessed 3 December 2010].

Spinks, N., Silburn, N., Birchall, D., 2006. Educating engineers for the 21 st century: The industry view, Henley Management College: Henley-on-Thames, Oxfordshire.

Walker, A. and Leary, H., 2009. A Problem Based Learning Meta Analysis: Differences cross Problem Types, Implementation Types, Disciplines, and Assessment Levels. Interdisciplinary Journal of Problem-based Learning, 3(1), 6-28.

Woods, D. R., 1994. Problem-based learning: How to gain the most from PBL. Griffin: Hamilton, Ontario.

\begin{tabular}{|l|c|c|c|c|}
\hline Graduates & Discipline & Vacation work & $\begin{array}{c}\text { Mid-study one } \\
\text { year placement }\end{array}$ & $\begin{array}{c}\text { Employment } \\
\text { duration at } \\
\text { time of } \\
\text { interview } \\
\text { (months) }\end{array}$ \\
\hline nonPBL1 & Chemical Eng & $\checkmark$ & & 8 \\
\hline nonPBL2 & Chemical Eng & $\checkmark$ & & 24 \\
\hline nonPBL3 & Chemical Eng & $\checkmark$ & $\checkmark$ & 14 \\
\hline nonPBL4 & Chemical Eng & $\checkmark$ & & 15 \\
\hline & & & & Average 15 \\
\hline PBL1 & Chemical Eng & $\checkmark$ & & 10 \\
\hline PBL2 & Chemical Eng & $\checkmark$ & & 12 \\
\hline PBL3 & Chemical Eng & $\checkmark$ & & 12 \\
\hline PBL4 & Chemical Eng & & $\checkmark$ & 10 \\
\hline PBL5 & Civil Eng & $\checkmark$ & & 12 \\
\hline PBL6 & Civil Eng & $\checkmark$ & & 5 \\
\hline & & & & Average 10 \\
\hline
\end{tabular}

Table 1: Details of participants

\begin{tabular}{|l|c|c|c|c|}
\hline Students attributed learning to: & \multicolumn{2}{|c|}{ PBL course } & \multicolumn{2}{c|}{ Vacation work } \\
\hline & $\begin{array}{c}\text { Non-PBL } \\
\text { graduates }\end{array}$ & $\begin{array}{c}\text { PBL } \\
\text { graduates }\end{array}$ & $\begin{array}{c}\text { Non-PBL } \\
\text { graduates }\end{array}$ & $\begin{array}{c}\text { PBL } \\
\text { graduates }\end{array}$ \\
\hline Project management & $\odot \odot$ & $\odot \odot$ & $\checkmark$ & $\checkmark \checkmark$ \\
\hline Problem solving & & & & \\
\hline $\begin{array}{l}\text { Communication and } \\
\text { consultation }\end{array}$ & & $\odot \odot \odot$ & $\checkmark$ & \\
\hline Sourcing information & & & & \\
\hline Awareness of sustainability & & & & \\
\hline Ethical considerations & & & & \\
\hline Technical skills & & & & \\
\hline $\begin{array}{l}\text { Systematic application of } \\
\text { engineering knowledge in } \\
\text { design }\end{array}$ & $\odot \odot \odot$ & $\begin{array}{c}\odot \odot \odot \\
-\odot \odot\end{array}$ & & \\
\hline
\end{tabular}

Table 2: Attribution of EA competence to undergraduate experience

๑ student identified a wish to have done more PBL courses

(-) student identified doing PBL courses assisted work transition

$\checkmark$ student identified doing vacation work assisted developing the attribute 